\title{
Composition, Diversity and Food Habits of the Fish Community of a Coastal Wetland in Ghana
}

\author{
Isaac Okyere (Corresponding Author) \\ E-mail: okyereisaac@yahoo.com \\ John Blay \\ E-mail: jblay7749@yahoo.co.uk \\ Joseph Aggrey-Fynn \\ E-mail: jafynn@yahoo.com \\ Denis Worlanyo Aheto \\ E-mail: worlaheden@yahoo.com
}

\begin{abstract}
Department of Fisheries and Aquatic Sciences, School of Biological Sciences University of Cape Coast, Cape Coast, Ghana
\end{abstract}

Received: May 30, 2011 Accepted: June 8, 2011 Published: December 24, 2011

doi:10.5296/jee.v3i1.892 URL: http://dx.doi.org/10.5296/jee.v3i1.892

\begin{abstract}
This study aims at stimulating the scientific community towards a better understanding of fish community ecology in relation to physico-chemical determinants in unmanaged coastal wetlands relevant for informed decision-making on ecosystem functioning and management in the tropical context. We investigated the diversity, size distribution and food habits of the fish community and the abiotic environmental conditions of the Kakum Estuary wetland in Ghana ( $5^{\circ} 6^{\prime} \mathrm{N} ; 1^{\circ} 18^{\prime} \mathrm{W}$ ) from July 2009 to February 2010. Eighteen species belonging to 18 genera and 12 families of marine, brackishwater and freshwater fishes were sampled. The poecilid Aplocheilichthys spilauchen (43.31\%), the cichlid
\end{abstract}




\section{Macrothink $\Lambda$ Institute"}

Sarotherodon melanotheron (18.12\%) and the freshwater shrimp Macrobrachium macrobrachion (12.37\%) were dominant. Fish communities in pools in the wetland were quite close in diversity $\left(H^{\prime}\right.$ ranged from 2.2 to 2.7$)$ and highly similar $\left(\mathrm{C}_{\mathrm{s}}>0.6\right)$ possibly as a result of the prevailing similar environmental conditions. Smaller individuals of the cichlids Tilapia zillii, Hemichromis fasciatus and S. melanotheron measuring 2.0-3.9 cm TL, and marine species such as Elops lacerta and Liza falcipinnis measuring 6.0-7.9 cm TL constituted between $60 \%$ and $80 \%$ of the populations, suggesting the wetland as nursery and feeding grounds for the fishes. Examination of stomach contents showed that the communities included detritivorous, planktivorous, insectivorous, omnivorous and piscivorous species. It is strongly recommended to restrict fishing in the wetland during the wet season to avoid exploitation of juvenile fishes which use the wetland as nursery and feeding grounds during that period.

Keywords: Coastal wetlands, Fish biodiversity, Community ecology, Trophic relations, Wetland management 


\section{Introduction}

The need for a better understanding of the role of biodiversity in the functioning of aquatic ecosystems has been raised by several authors (Little et al., 1988; Ryan \& Ntiamoa-Baidu, 2000; Scherer-Lorenzen, 2005; Duarte et al., 2006). Humbert and Dorigo (2005) have indicated that ecosystem functioning depends on several factors including biodiversity and a multiplicity of interactions between the physical, chemical and biological determinants. According to Lévêque (1995), several studies attribute ecosystem function largely to processes such as storage and transfer of matter and energy at different temporal and spatial scales. Scherer-Lorenzen (2005) also argues that the function of an ecosystem is highly dependent on the functional traits of the organisms involved as well as the abiotic environment. In agreement with Scherer-Lorenzen (2005), Humbert and Dorigo (2005) pointed out that knowledge of the functional traits of biodiversity and ecological interaction between the biotic and abiotic environments is crucial for informed management decisions. This study reports on the composition, diversity, size distribution and food habits of the fish community in the Kakum Estuary wetland in Ghana. The data could be used to support efforts that aim at improving fish and ecosystem productivity in unmanaged coastal wetlands in West Africa.

The present study is important for several compelling reasons. Coastal wetlands are among the most biologically productive but least understood ecosystems in the world (Ryan \& Ntiamoa-Baidu, 2000). In Ghana, they are reported to be the most diverse aquatic habitats (Gordon et al., 1998). Ghana's $550 \mathrm{~km}$ coastline contains over 100 lagoons and estuaries and their associated floodplains (Yankson \& Obodai, 1999) of which only five (MuniPomadze, Sakumo, Songor, and Keta Lagoons, and Densu delta) with surface area ranging from 1364 ha to 101022 ha are presently managed as Ramsar sites (Willoughby et al., 2001; Quashie \& Oppong, 2006). This study is of significance because the smaller coastal wetlands which are greater in number have been neglected in terms of management and regulatory interventions. This is partly due to a lack of adequate knowledge on the ecology of these wetlands that could advance the understanding of their contributory functions (Attuquayefio \& Gbogbo, 2001; Gbogbo, 2007). For countries in West Africa that are signatory to the Ramsar Convention, this study provides an important insight of fish assemblages and diversity of fish biota, and will thus encourage studies to cover a greater number of such wetlands in the sub-Region.

As indicated by Scherer-Lorenzen (2005), the functional status of aquatic ecosystems is largely determined by the functional traits of the biodiversity together with the abiotic environment. Hence, assessing the biodiversity and interactions between the biotic communities and the abiotic factors of wetlands would give a broader understanding of the functions and ecological value of these ecosystems since biodiversity of wetland ecosystems is closely tied to the abiotic conditions (Quinn, 1980; Little et al., 1988).

This paper therefore aims at investigating the ecological value of an unmanaged coastal wetland in Ghana based on some environmental conditions, diversity of fish species and food habits of the fish community in order to provide baseline information for management and conservation planning of the wetland. The specific objectives of the 
study are to broaden the knowledge on the fish community structure and ecological importance of the Kakum Estuary wetland in Ghana by investigating (a) some physicochemical parameters (b) the species composition and diversity of the fish community, and (c) the feeding ecology of the fishes.

\section{Materials and Methods}

\subsection{Study area}

The Kakum Estuary wetland is a salt marsh located about $2 \mathrm{~km}$ west of Cape Coast in the Central Region of Ghana (approximately $5^{\circ} 6^{1} \mathrm{~N} ; 1^{\circ} 18^{1} \mathrm{~W}$ ). It is associated with the Kakum River Estuary which lies to the west of the wetland. The dominant flora includes the saltwater couch Paspalum vaginatum (Poaceae), the sedge-grass Cyperus articulatus (Cyperaceae) and the bulrush Typha australis (Typhaceae). The thatch grass Imperata cylindrica (Poaceae) and coconut trees Cocos nucifera (Palmae) fringe the stretch of sandy beach separating the wetland from the Atlantic Ocean while the western portion is bordered by mangroves. In the wet season (May to August), flood waters from the Kakum River inundate the wetland and fish become abundant. The area is characterized by isolated pools during the period of dry season (October to March).

\subsection{Sampling of physico-chemical parameters and fish species}

The study was conducted from July 2009 to February 2010, covering parts of the wet and dry seasons. Five relatively large pools in the wetland were selected for the study. These pools were selected to ensure that sampling extended well into the dry season as the smaller pools tended to dry up rapidly sooner with the onset of the dry season. The area (A) of a near square or rectangular pool was estimated as the product of the length and width, and the area of approximately circular pools was calculated as $\pi r^{2}$, where $\mathrm{r}$ is the radius of the pool. The maximum depth of each pool was also determined monthly at the deepest part using a meter rule.

Fish sampling and measurement of hydrographic parameters were undertaken between the $20^{\text {th }}$ and $22^{\text {nd }}$ day of each month. Temperature, salinity and conductivity were measured with a YSI Incorporated (Model 63) meter. Turbidity was measured with a turbidimeter (TOA Model TB-1A) and $\mathrm{pH}$ with a portable $\mathrm{pH}$ meter (Corning Incorporated Model 220). Dissolved oxygen (DO) content of pools was also determined by the modified Winkler's titrametric method using a HACH test kit (Model FF2). Three measurements of each parameter were taken at different points in each pool on each sampling date.

A pole-seine net ( $7 \mathrm{~m}$ long and $1.5 \mathrm{~m}$ deep) with stretched mesh size of $5 \mathrm{~mm}$ was used to sample the fish. The fishes were preserved in $10 \%$ formalin immediately after capture to arrest post mortem digestion of stomach contents and transported to the laboratory for further examination. The fish were identified to their families and species level using manuals and keys on finfishes and shellfishes from Ghana and other parts of West Africa (Rutherford, 1971; Schneider, 1990; Dankwa et al., 1999; Paugy et al., 2003), and the number of individuals belonging to each species from the pools was recorded. 
The total length (TL) of finfish; , carapace width (CW) of crabs and body length (BL) of shrimp specimens were measured to the nearest $0.1 \mathrm{~cm}$ and the body weight $(\mathrm{BW})$ of the finfishes and shellfishes were determined to the nearest $0.01 \mathrm{~g}$. Finfish were dissected and the content of the stomach examined using a dissecting microscope where necessary. Diversity of the fish communities was ascertained by the Shannon-Wiener index $\left(\mathrm{H}^{\prime}\right)$ given as $\mathrm{H}^{\prime}=-\sum_{i=1}^{s} P_{i}\left(\ln P_{i}\right)$, where $s$ is the number of species in the community and $P_{i}$ is the proportion of individuals belonging to species $i$ in the community (Krebs, 1999). The evenness or equitability component of diversity was calculated from Pielou's index (Pielou, 1966) given as $J^{\prime}=\mathrm{H}^{\prime} / \mathrm{H}_{\max }$ where $\mathrm{H}_{\max }=\ln s$. The degree of similarity between the fish communities in the different pools was determined as $C_{s}=\frac{2 j}{a+b} \quad$ (Krebs, 1999), where $C_{s}$ is Sorensen's index, $j$ is the number of species common to a given pair of pools, and $a$ and $b$ are the number of species occurring in either of the two pools. Stomach contents were analyzed using the frequency of occurrence method and the "points" method (Hyslop, 1980; Lima-Junior \& Goitein, 2001) based on a four point scale: 10 points for full stomach, 7.5 for three-quarters, 5 for half and 2.5 for quarter filled stomach. The percentage composition of each of the food items was estimated.

\section{Results}

\subsection{Wetland environmental conditions}

The surface area of the pools at the start of the observations in July 2009 were $2680 \mathrm{~m}^{2}$ (Pool V), $779 \mathrm{~m}^{2}$ (Pools I), $759 \mathrm{~m}^{2}$ (Pool III), $754 \mathrm{~m}^{2}$ (Pool IV), and $661 \mathrm{~m}^{2}$ (Pool II), and all were nearly $1 \mathrm{~m}$ deep until the pools dried completely in November 2009 (Pool I), December 2009 (Pool IV), January (Pools II and III) and February 2010 (Pool V).

Table 1 presents averages of the environmental parameters recorded during the study period. Physico-chemical conditions were highly similar among the pools except dissolved oxygen concentration which was relatively higher in Pool V. Salinity (1.9 \%o to $3.2 \%$ ) was far lower than that of seawater, indicating that the pools were brackish.

Table 1. Mean values of physico-chemical parameters recorded from the five pools in the Kakum Estuary Wetland from July 2009 to January 2010 (standard errors in parenthesis)

\begin{tabular}{|c|c|c|c|c|c|}
\hline Parameter & Pool I & Pool II & Pool III & Pool IV & Pool V \\
\hline Temperature $\left({ }^{\circ} \mathrm{C}\right)$ & $32.6(4.9)$ & $35.8(5.5)$ & $35.9(6.1)$ & $35.4(4.7)$ & $37.8(6.9)$ \\
\hline Salinity $(\%)$ & $1.9(1.5)$ & $2.8(1.57)$ & $2.7(1.6)$ & $2.3(1.4)$ & $3.2(1.8)$ \\
\hline Conductivity $\left(\mu \mathrm{Scm}^{-1}\right)$ & $4636(36)$ & $6611(3876)$ & $6827(3809)$ & $5121(3319)$ & $7355(4175)$ \\
\hline $\mathrm{DO}(\mathrm{mg} / \mathrm{L})$ & $3.4(0.7)$ & $3.9(0.9)$ & $3.7(0.9)$ & $4.2(0.9)$ & $5.2(0.3)$ \\
\hline Turbidity $(\mathrm{ppm})$ & $165(77)$ & $163(79)$ & $204(91)$ & $122(28)$ & $225(85)$ \\
\hline $\mathrm{pH}$ & $7.4(1.0)$ & $7.7(0.7)$ & $7.8(0.8)$ & $7.6(0.5)$ & $7.9(0.7)$ \\
\hline
\end{tabular}




\subsection{Occurrence of fish species}

Sixteen species of finfish belonging to 16 genera and 10 families were found in the pools (Table 2). Two shellfish species were also found in the pools. Eight species, namely Hemichromis fasciatus, Sarotherodon melanotheron, Tilapia zillii, Kribia kribensis, Liza falcipinnis, Aplocheilichthys spilauchen, Macrobrachium macrobrachion and Callinectes amnicola occurred in all the five pools. Porogobius schlegelii occurred in four pools and two species Clarias gariepinus and Eleotris senegalensis occurred in three pools. Two of the pools were inhabited by Elops lacerta, Hepsetus odoe and Odaxothrissa mento while one of the pools was inhabited by Bathygobius soporator, Periophthalmus barbarus, Barbus sp. and Dormitator lebretonis.

Table 2. Occurrence of fish species in the Kakum Estuary wetland in pools

\begin{tabular}{|c|c|c|c|c|c|c|}
\hline \multirow{2}{*}{ Family } & \multirow{2}{*}{ Species } & \multicolumn{4}{|c|}{ Pool } & \multirow[b]{2}{*}{$\mathrm{V}$} \\
\hline & & $\mathrm{I}$ & II & III & IV & \\
\hline \multirow[t]{3}{*}{ CICHLIDAE } & Hemichromis fasciatus & + & + & + & + & + \\
\hline & Sarotherodon melanotheron & + & + & + & + & + \\
\hline & Tilapia zillii & + & + & + & + & + \\
\hline CLARIIDAE & Clarias gariepinus & + & + & - & - & + \\
\hline CLUPEIDAE & Odaxothrissa mento & - & - & + & - & + \\
\hline CYPRINIDAE & Barbus sp. & - & - & + & - & - \\
\hline \multirow[t]{3}{*}{ ELEOTRIDAE } & Kribia kribensis & + & + & + & + & + \\
\hline & Eleotris senegalensis & + & + & - & - & + \\
\hline & Dormitator lebretonis & - & - & - & + & - \\
\hline ELOPIDAE & Elops lacerta & - & + & - & - & + \\
\hline \multirow[t]{3}{*}{ GOBIIDAE } & Porogobius schlegelii & + & + & + & - & + \\
\hline & Bathygobius soporator & - & - & - & + & - \\
\hline & Periophthalmus barbarus & - & - & - & - & + \\
\hline HEPSETIDAE & Hepsetus odoe & + & - & + & - & - \\
\hline MUGILIDAE & Liza falcipinnis & + & + & + & + & + \\
\hline POECILIIDAE & Aplocheilichthys spilauchen & + & + & + & + & + \\
\hline PALAEMONIDAE & Macrobrachium macrobrachion & + & + & + & + & + \\
\hline PORTUNIDAE & Callinectes amnicola & + & + & + & + & + \\
\hline
\end{tabular}


3.3 Fish species composition

Figure 1 shows the percentage composition of the species in each pool. The poecilid fish Aplocheilichthys spilauchen was dominant in all the pools, with the composition ranging from $26.21 \%$ to $59.23 \%$. T. zillii (Cichlidae), S. melanotheron (Cichlidae) and the freshwater shrimp Macrobrachium macrobrachion (Palaemonidae) were the second most abundant species in some of the pools (15.1\% to $20.1 \%)$.
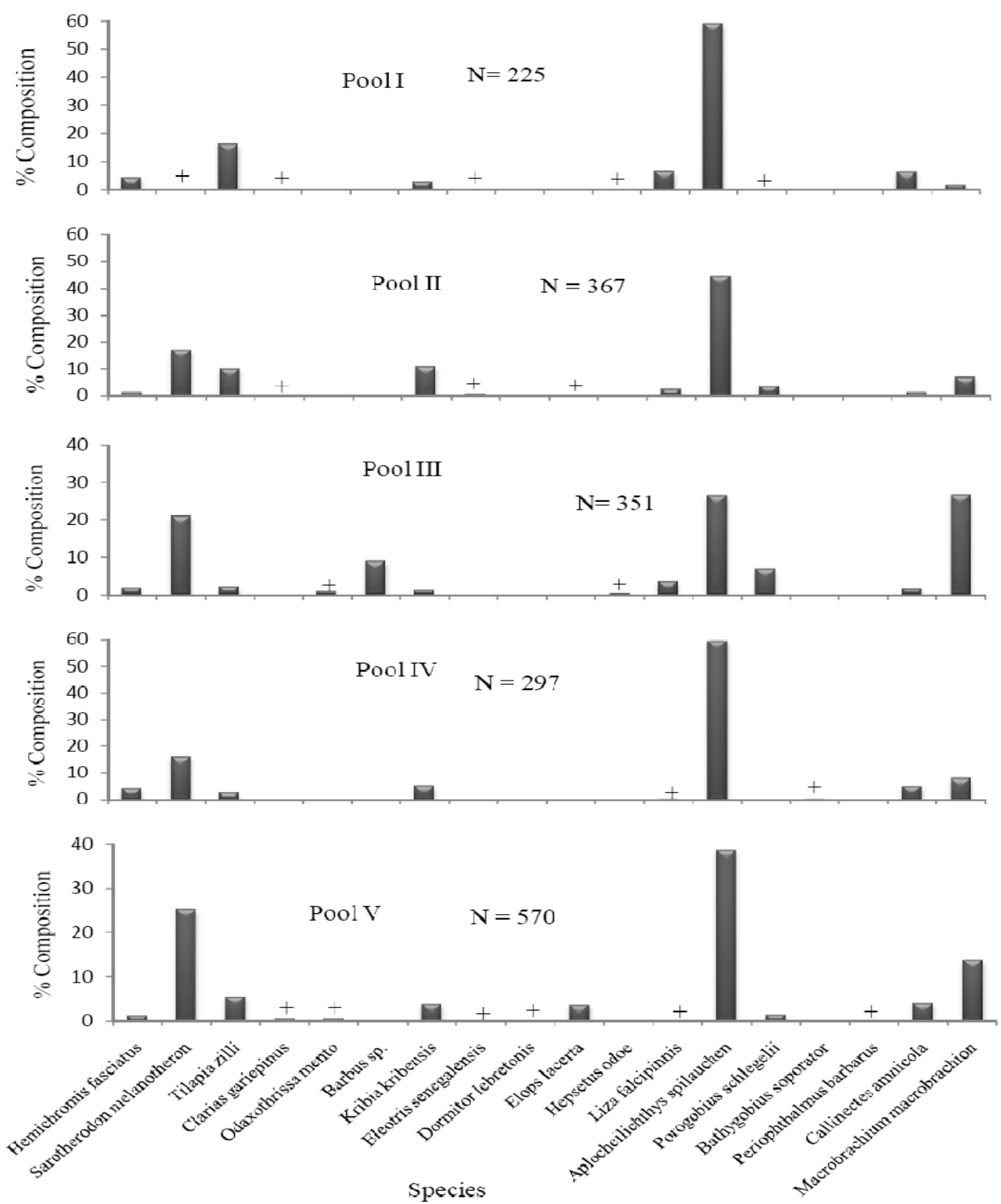

Figure 1. Percentage composition of fish species in five pools in Kakum Estuary wetland ( + indicates $<0.5 \%$ composition) 
3.4 Species diversity and similarity of fish communities

Values of the diversity and equitability indices for the fish communities are presented in Table 3. The diversity index $\left(H^{\prime}\right)$ ranged from 2.2 to 2.7 , and the equitability index from 0.6 to 0.7 . These results indicate little difference in the species diversity of the fish communities. Species richness was highest in Pool V (15 species) and lowest in Pool IV (9 species).

Sorensen's similarity $\left(C_{s}\right)$ values ranged from 0.7 to 0.9 (Table 4 ) suggesting a generally high similarity among the fish communities in the pools.

Table 3. Species richness and diversity indices for fish communities in the five wetland pools

\begin{tabular}{|l|c|c|c|}
\hline Pool & No. of species & $H^{\prime}$ & $J^{\prime}$ \\
\hline Pool I & 12 & 2.5 & 0.6 \\
\hline Pool II & 12 & 2.5 & 0.7 \\
\hline Pool III & 12 & 2.5 & 0.7 \\
\hline Pool IV & 9 & 2.2 & 0.6 \\
\hline Pool V & 15 & 2.7 & 0.7 \\
\hline & $H^{\prime}=$ Shannon-Wiener index; $J^{\prime}=$ Equitability index \\
\hline
\end{tabular}

Table 4. Sorensen's similarity index for the pairs of fish communities

\begin{tabular}{|c|c|c|c|c|c|}
\hline & Pool I & Pool II & Pool III & Pool IV & Pool V \\
\hline Pool I & & & & & \\
\hline Pool II & 0.917 & & & & \\
\hline Pool III & 0.833 & 0.750 & & & \\
\hline Pool IV & 0.762 & 0.762 & 0.762 & & \\
\hline Pool V & 0.815 & 0.889 & 0.741 & 0.667 & \\
\hline
\end{tabular}

\subsection{Fish size range}

Table 5 gives the size range and modal sizes of the fish caught in the wetland. $A$. spilauchen ranged from $2.4 \mathrm{~cm}$ to $5.1 \mathrm{~cm}$ TL, with a modal class of 3.0-3.9 cm while $S$. melanotheron ranged from $1.4 \mathrm{~cm}$ to $10.5 \mathrm{~cm}$ TL with individuals measuring $2.0-2.9 \mathrm{~cm}$ forming the mode (76.3\%). The shrimp M. macrobrachion measured $2.2 \mathrm{~cm}-9.4 \mathrm{~cm} \mathrm{BL}$ with $63.9 \%$ of the individuals measuring $4.0-4.9 \mathrm{~cm}$. Some marine fishes found such as the E. lacerta had a range of $3.8 \mathrm{~cm}-8.8 \mathrm{~cm}$ TL with $6.0-6.9 \mathrm{~cm}$ being the modal length. The mullet L. falcipinnis measured $6.2 \mathrm{~cm}-13.6 \mathrm{~cm}$ with modal length of 7.0-7.9 $\mathrm{cm}$ (63.3\%) while the swimming crab C. amnicola ranged from $1.0 \mathrm{~cm}$ to $7.2 \mathrm{~cm}$ carapace width, with individuals measuring 1.0-1.9 $\mathrm{cm} \mathrm{CW}$ dominating the population (73.2\%). 
Table 5. Size range of fish species sampled (all pools) from the Kakum Estuary wetland

\begin{tabular}{|c|c|c|c|c|c|}
\hline \multirow{2}{*}{ Species } & \multirow{2}{*}{ No. } & \multicolumn{4}{|c|}{ TL(cm) } \\
\hline & & Min & Max & Modal class & Composition \\
\hline \multicolumn{6}{|l|}{ Finfish } \\
\hline Hemichromis fasciatus (FW) & 41 & 3.5 & 12 & $3.0-3.9$ & $62.4 \%$ \\
\hline Sarotherodon melanotheron (BW) & 328 & 1.4 & 10.5 & $2.0-2.9$ & $76.3 \%$ \\
\hline Tilapia zillii $(\mathrm{FW})$ & 121 & 1.4 & 6.9 & $2.0-2.9$ & $69.6 \%$ \\
\hline Clarias gariepinus $(\mathrm{FW})$ & 7 & 10.4 & 24.1 & - & - \\
\hline Odaxothrissa mento (FW) & 7 & 8 & 16.6 & - & - \\
\hline Barbus sp.(FW) & 31 & 3.1 & 4.7 & $3.0-3.9$ & $43.2 \%$ \\
\hline Kribia kribensis (FW) & 88 & 3.6 & 6.2 & $5.0-5.9$ & $68.4 \%$ \\
\hline Eleotris senegalensis (FW/BW) & 6 & 3.4 & 6.3 & - & - \\
\hline Dormitator lebretonis (FW/BW) & 1 & - & - & - & - \\
\hline Elops lacerta $(\mathrm{M})$ & 22 & 3.8 & 8.8 & $6.0-6.9$ & $60.2 \%$ \\
\hline Hepsetus odoe (FW) & 2 & - & 19.5 & - & - \\
\hline Liza falcipinnis (M/BW) & 39 & 6.2 & 13.6 & $7.0-7.9$ & $63.3 \%$ \\
\hline Aplocheilichthys spilauchen (FW) & 784 & 2.4 & 5.1 & $3.0-3.9$ & $32.1 \%$ \\
\hline Porogobius schlegelii (FW/BW) & 47 & 4.1 & 8.1 & $5.0-3.9$ & $42.3 \%$ \\
\hline Bathygobius soporator (M/BW) & 1 & - & - & - & - \\
\hline Periophthalmus barbarus (BW) & 1 & - & - & - & - \\
\hline \multicolumn{6}{|l|}{ Shellfish } \\
\hline Callinectes amnicola (M/BW) & 60 & $1.0^{*}$ & $7.2^{*}$ & $1.0-1.9 *$ & $73.2 \%$ \\
\hline Macrobrachium macrobrachion (FW) & 224 & 2.2 & 9.4 & $4.0-4.9$ & $63.9 \%$ \\
\hline
\end{tabular}

\subsection{Food spectrum}

The food items consumed by a particular fish species in the five pools did not vary significantly, hence the samples were combined to determine the frequency of occurrence and composition of food items in the stomachs (Figure 2).

\section{Aplocheilichthys spilauchen}

This species fed mainly on insects (97.0\% occurrence, $33.1 \%$ composition), chironomid larvae (40.0\% occurrence, composition of $12.1 \%)$, other unidentified insect larvae $(78.0 \%$ occurrence, $30.4 \%$ composition) and debris (89.0\% occurrence, $20.1 \%$ composition). Copepods were lowly consumed.

\section{Sarotherodon melanotheron}

Diatoms (e.g. Navicula, Rhizosolenia, Gyrosigma and Stephanodiscus) were encountered in all stomachs containing food with a composition of $50.8 \%$, followed by debris $(64.8 \%$ and $26.1 \%$ by occurrence and composition respectively). Green algae (eg. Pediastrum, Staurastrum and Closterium) and blue - green algae (Anabaena, Oscillatoria, Chroococcus and Microcystis) had frequencies of occurrence as $31.0 \%$ and $14.0 \%$ 
respectively, and compositions of $8.4 \%$ and $5.8 \%$ respectively. Zooplankton, zoobenthos and other food items varied between $1 \%$ and $5 \%$ in occurrence and composition.

Tilapia zillii

Plant material ( $98.0 \%$ by occurrence) and algae (100\% by occurrence) were the most frequently ingested food of T. zillii, constituting $51.5 \%$ and $34.1 \%$ respectively of the consumed food. This was followed by debris with occurrence of $53.4 \%$ and composition of $10.6 \%$ while copepods and rotifers were ingested by $6.65 \%$ and $9.95 \%$ of the specimens respectively, and made up $1.61 \%$ and $2.21 \%$ respectively of the consumed food.

\section{Liza falcipinnis}

Similarly, the most important food eaten by L. falcipinnis were diatoms (100\% by occurrence, $41.6 \%$ by composition) and debris (80.0\% occurrence, $30.3 \%$ composition). Blue-green algae, green algae and copepods had occurrence of $26.6 \%, 46.7 \%$ and $40 \%$ respectively, and compositions of $8.3 \%, 4.7 \%$ and $7.1 \%$ respectively. Few individuals preyed on rotifers and other zooplankton ( $<20 \%$ frequency) and their composition was less than $5 \%$ of the stomach contents.

\section{Hemichromis fasciatus}

Among the items eaten by $H$. fasciatus, insect fragments ( $75.6 \%$ by occurrence) and fish fry $(95.1 \%$ by occurrence) were found to constitute the most common preys, with compositions of $28.97 \%$ and $30.84 \%$ respectively. Insect larvae (principally chironomid larvae) were found in the stomachs of $68.2 \%$ of the specimens and composed $17.2 \%$ of the food while shrimps were ingested by $58 \%$ of the fish and made up $12.6 \%$ of the prey ingested. Fish scales, copepods, algae (e.g. diatoms, green and blue-green algae) and debris occurred in $<10 \%$ of the stomachs and they composed $4 \%$ of the food consumed.

\section{Porogobius schlegelii}

All the specimens of $P$. schlegelii also fed mainly on copepods. Copepods were the most ingested prey which formed almost $48 \%$ of the stomach contents. Debris (34\%) and oligochaetes (16\%) also constituted a very important component of the food while fish scales were encountered in less than $5 \%$ of the specimens and made up $2 \%$ of the total consumed food.

\section{Kribia kribensis}

The K. kribensis specimens had debris, chironomid larvae, copepods and annelids (oligochaetes) in their stomachs, with copepods being the most common prey with a composition of $33.5 \%$ of the food. Chironomid larvae were the next most consumed prey with a composition of $27.2 \%$ while oligochaetes (annelid) comprised $22.6 \%$ of the ingested food. About $16.7 \%$ of the stomach content was debris. 

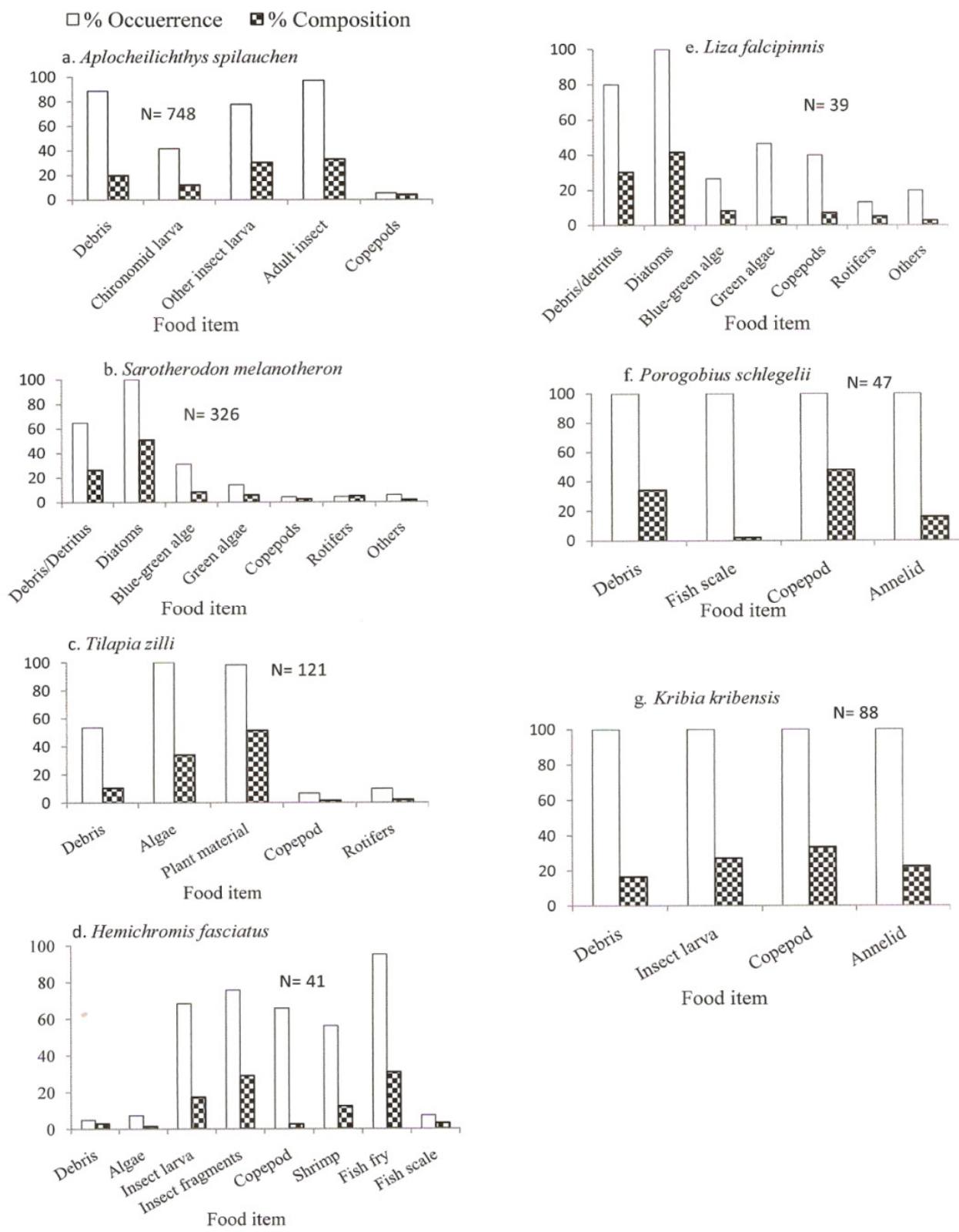

Figure 2. Percentage occurrence and composition of food items in the diet of seven fish species in the Kakum Estuary wetland

\section{Other species}

Debris or detritus represented $60 \%$ by composition and chironomid larvae $40 \%$ by composition of the food consumed by other fish species. These were found to be the only food items consumed by all the 31 specimens of Barbus sp. The one specimen each of the gobies P. barbarus and Bathygobius soporator as well as Dormitator lebretonis fed on detritus, chironomid larvae and copepods. All six Eleotris senegalensis examined took chironomid larvae, copepods, debris and oligochaetes which made up $36.4 \%, 28.2 \%, 21.3 \%$ and $14.1 \%$ of the food content respectively. Fragments of adult insects and juvenile shrimps were the only components of the food of all 7 individuals of Odaxothrissa mento 
in the wetland, each food item constituting about $50 \%$ of the diet. Elops lacerta (23 specimens) preyed exclusively on juvenile shrimps and fish fry (each made up $50 \%$ of the diet), and the 2 specimens of Hepsetus odoe found had ingested only fish. Seven specimens of the catfish Clarias gariepinus were found to have consumed fishes, chironomid larvae, plant materials, algae and debris.

\section{Discussion}

\subsection{Composition, diversity and size distribution of the fish communities}

Salinity has been recognised as a key factor influencing the occurrence and composition of species in brackishwater habitats in the tropics and subtropics (Little et al., 1988). This is because species differ in salinity tolerance. Although the pools in the Kakum estuary wetland were brackish (mean salinity varied between $1.9 \%$ and $3.2 \%$ ), salinity could not be linked with the presence or absence of any of the species in the pools. This is presumably due to the fact that salinity did not differ markedly among the pools.

The relatively larger size of Pool V, coupled with its higher oxygen content seemed to be the major factor that accounted for its correspondingly higher fish species diversity. Furthermore, the closeness of the diversity indices is reflected in the communities being very similar and this is buttressed by the high similarity index values $\left(\mathrm{C}_{\mathrm{s}}>0.6\right)$. This finding could also be as a result of the prevailing highly similar environmental conditions. The 18 species belonging to 12 families recorded in the wetland is lower than that of the nearby Kakum River Estuary where Blay (1997) found 28 species belonging to 14 families. Apparently, due to its permanent connection to the sea, more species enter the estuary than the adjacent wetland where most fishes enter only during the wet season when it is flooded by the Kakum River.

A. spilauchen, S. melanotheron and M. macrobrachion were dominant and together made up over $73 \%$ of the community in each pool. This community structure is similar to reports by some researchers which indicate dominance of a few species in the total fish biomass of brackishwater habitats (Quinn, 1980; Little et al., 1988; Green et al., 2009).

Coastal wetlands serve as important breeding and nursery grounds for many commercially important fishes. Reports on the structure of fish communities of salt marshes along the Essex coastline (UK) (Green et al., 2009) and a salt marsh intertidal creek in the Yangtze River Estuary (China) (Jin et al., 2007) showed that juveniles of commercially important species dominated the catches from the marshes. These workers therefore underscored the importance of salt marshes as nursery habitats and the need for conservation of such habitats.

Results of the present study have similarly shown the Kakum estuarine wetland serves important but different purposes for different fish groups at different life stages. The blackchinned tilapia $S$. melanotheron which is the mainstay of the fishery of many West African lagoons and an abundant fish in the wetland had a modal size of 2.0-2.9 cm TL (76.3\%), which is far smaller than the $4.6 \mathrm{~cm} \mathrm{SL}(=5.5 \mathrm{~cm} \mathrm{TL})$ estimated as the maturity length $\left(\mathrm{Lm}_{50}\right)$ for the population in the adjacent Kakum River Estuary (Blay, 1998). Similarly, the 
shrimp M. macrobrachion which was also common in the wetland, and constituted an important food resource exploited by the local communities had $63 \%$ of the samples comprising smaller individuals (modal size 4.0-4.9 cm BL), with most of the few adults encountered being gravid females. Besides these commonly encountered fishes, juveniles of marine fishes including L. falcipinnis, E. lacerta, P. schlegelii, B. soporator and the crab C. amnicola which had earlier been reported in the Estuary (Blay, 1997) were also encountered in the wetland. These findings indicate that the wetland is utilized as a feeding ground by juvenile marine fishes while freshwater species use the wetlands for breeding as well as nursery and feeding grounds.

\subsection{Food habits and trophic relationships}

The main constituents of the diet of $A$. spilauchen in the pools were debris, insect larvae and adult insects, with copepods representing a very small proportion of the food, as also reported by Dankwa et al. (1999). The food of S. melanotheron in the wetland did not differ markedly from that of populations in the Sakumo Lagoon in Ghana (Ofori-Danson \& Kumi, 2006) and Eleiyele reservoir (Ayoade \& Ikulala, 2007) and Awba Reservoir (Ugwumba \& Adebisi, 1992) in Nigeria, except that these populations fed on a wider range of algae and zooplankton. Similarly, the grey mullet L. falcipinnis occurring in the wetland fed on similar items taken by mullets in Benya lagoon in Ghana (Blay, 1995), and River Pra and River Volta estuaries also in Ghana (Dankwa et al., 2005). However, the lagoon and estuarine populations ingested a broader spectrum of food items including red algae, molluscan larvae, polychaetes and nematodes which were absent in the diet of the present population. Therefore the relatively narrow spectrum of food eaten by the fish encountered in the present study suggests the unavailability of a number of their dietary items in the wetland.

T. zillii fed mainly on plant materials and debris, confirming their macrophagous food habits (Dankwa et al., 1999) while H. fasciatus preyed on variety of items, from larvae and adult of insects to shrimps and fish fry, which confirms their minor-piscivorous feeding habit (Dankwa et al., 1999). Comparatively, the food consumed by the populations of H. fasciatus in Tarkwa bay and the Lagos lagoon in Nigeria (Ugwumba, 1988) consisted principally of fish. The differences in the variety of prey consumed by the wetland population and those in Nigeria could be related to the availability, abundance and diversity of potential prey in their respective environments.

Fishes of the family Eleotridae and Gobiidae are generally known to be carnivores (Dankwa et al., 1999) and this predatory habit manifested in their diet in the wetland. Although $K$. kribensis and P. schlegelii exploited similar food resource (copepods, oligochaetes and debris), the former additionally consumed chironomid larvae to a considerable extent $(27 \%$ composition) while the latter ingested fish scales $(2 \%)$. This could suggest a trophic divergence or habitat segregation among the species to reduce or avoid interspecific competition. Unlike the four species of eleotrids in freshwater streams of the Caribbean coast (Costa Rica) which had diets dominated by shrimps and fishes (Winemiller \& Ponwith, 1998), those in Kakum did not consume such items despite their abundance in the pools, which indicates that though eleotrids are generally predatory, prey 
items may vary for different species.

Blay (1996) found eleven items in the food of the P. schlegelii population in the Fosu lagoon (Ghana) and these included detritus, fish scales, copepods, algae, rotifers, fish fry, insect larvae and some plant materials. In the present study, only the first three items, together with oligochaetes were eaten by the Kakum wetland population while other predatory fishes fed on the other items. Considering that several macrophagous species occurred in the wetland pools compared to the lagoon where $P$. schlegelii is the only macrobenthophagous fish present (Blay \& Asabre-Ameyaw, 1993), it is conceivable that the consumption of such a narrow range of prey could be a resource partitioning mechanism to reduce competition.

$O$. mento fed on adult insects and juvenile shrimps while E. lacerta preyed on juvenile shrimps and fish fry indicating that both are carnivorous. The cyprinid Barbus sp. ingested debris and chironomid larvae suggesting that the species is detritivorous. Unfortunately, the dearth of information on the food habits of these three species constrains a comparison of their dietary items and food spectrum with populations elsewhere. Nevertheless, this study could serve as a reference point for future studies on the food habits of these fish species in Ghana and other West African countries.

\subsection{Conclusion}

In conclusion, the present study has demonstrated that the Kakum estuary wetland supports diverse freshwater, brackish and marine fish species which can be grouped into the various trophic guilds given by Esteves et al. (2008) and Green et al. (2009) namely microherbivore-detritivores (Sarotheodon melanotheron, Tilapia zillii and Liza falcipinnis), invertivore-detritivores (Barbus sp., Kribia kribensis, Eleotris senegalensis, Dormitator lebretonis, Porogobius schlegelii, Bathygobius soporator and Periophthalmus barbarus), insectivore (Aplocheilichthys spilauchen) minor - piscivores (Hemichromis fasciatus, Odaxothrissa mento and Elops lacerta), piscivore (Hepsetus odoe) and omnivore (Clarias gariepinus). Most of these fishes were represented by small individuals indicating that the wetland is an important nursery and feeding ground for the fishes, some of which are commercially important in the Ghanaian fishery. It is therefore recommended that fishing be restricted in the wetland prior to separation of the pools from the main river channel during the wet season in order to avoid exploitation of the juvenile fishes. It is also advisable that the country's fisheries policy and National Wetlands Conservation Strategy should consider this recommendation for implementation in cooperation with the local authorities in a co-management effort.

\section{Acknowledgements}

The authors are grateful to the Department of Fisheries and Aquatic Sciences of the School of Biological Sciences, University of Cape Coast, Ghana for providing a vehicle, field and laboratory equipment as well as laboratory space for this research. We also wish to express our gratitude to the chief technician Mr. Peter Aubyn as well as the field assistants Mr. John Eshun and Mr. Benjamin Owusu of School of Biological Sciences, UCC for their tireless efforts throughout the study. 


\section{References}

Attuquayefio, D. K. \& Gbogbo, F. (2001). Prospects of conserving the wetlands along the Mukwe Lagoon at Nungua in the Greater Accra Region of Ghana. West African Journal of Applied Ecology, 2, 65-75.

Ayoade, A. A. \& Ikulala, A. O. O. (2007). Length-weight relationship, condition factor and stomach contents of Hemichromis bimaculatus, Sarotherodon melanotheron and Chromidotilapia guentheri (Perciformes: Cichlidae) in Eleiyele Lake, Southwestern Nigeria. International Journal of Tropical Biology, 55(3-4), 969-977.

Blay, J. Jr. \& Asabere-Ameyaw, A. (1993). Assessment of the fishery of a stunted population of the cichlid, Sarotherodon melanotheron (Rueppell) in a "closed" lagoon in Ghana. Journal of Applied Ichthyology, 9, 1-11. http://dx.doi.org/10.1111/j.14390426.1993.tb00382.x

Blay, J. Jr. (1995). Food and feeding habits of four species of juvenile mullets (Mugilidae) in a tidal lagoon in Ghana. Journal of Fish Biology, 46, 134-141. http://dx.doi.org/10.1111/j.1095-8649.1995.tb05952.x

Blay, J. Jr. (1996). Aspects of the feeding biology of Porogobius schlegelii (Gunther) (Pisces: Gobiidae) in the Fosu lagoon, Ghana. Ghana Journal of Science, 31-36, 157-161.

Blay, J. Jr., (1997). Occurrence and diversity of juvenile marine fishes in two brackishwater systems in Ghana. In: D. S. Amlalo, L. D. Atsiatorme \& C. Fiati (Eds.), Biodiversity Conservation: Traditional Knowledge and Modern Concepts (pp. 113-119). UNESCO-BRAAF Proceedings, Cape Coast.

Blay, J. Jr. (1998). Growth and mortality parameters of Sarotherodon melanotheron melanotheron (Teleostei: Cichlidae) in two brackish water systems in Ghana. Ghana Journal of Science, 38, $47-55$.

Dankwa, H. R., Abban, E. K. \& Teugels, G. G. (1999). Freshwater Fishes of Ghana. Annales Sciences Zoologiques: Vol 283. p. 53.

Dankwa, H. R., Blay, J. Jr. \& Yankson, K. (2005). Food and Feeding Habits of Grey Mullets (Pisces: Mugilidae) in Two Estuaries in Ghana. West African Journal of Applied Ecology, 8, 65-77.

Duarte, P., Macedo, M. F. \& Fonseca, L. C. The relationship between phytoplankton diversity and community function in a coastal lagoon. Hydrobiologia, 555, 3-18. http://dx.doi.org/10.1007/s10750-005-1101-9

Esteves, K. E., Lobo, A. V. P. \& Faria, M. D. R. (2008). Trophic structure of a fish community along environmental gradients of a subtropical river (Paraitinga River, Upper Tiete ${ }^{\wedge} \quad$ River Basin, Brazil). Hydrobiologia, 598, 373-387. http://dx.doi.org/10.1007/s10750-007-9172-4

Gbogbo, F. (2007). The importance of unmanaged coastal wetlands to water birds at coastal Ghana. African Journal of Ecology, 45, 599-606. http://dx.doi.org/10.1111/j.1365- 
2028.2007.00778.x

Gordon, C., Yankson, K., Biney, C. A., Amlalo, D. S., Tumbulto, J. W. \& Kpelle, D. (1998). Report of the Working Group on Wetland Typology: Ghana Coastal Wetlands Management Project Background Documentation for the Ghana National Wetland Strategy. Department of Game and Wildlife, Government of Ghana.

Green, B. C., Smith D. J., Earley, S. E., Hepburn, L. J. \& Underwood, G. J. C. (2009). Seasonal changes in community composition and trophic structure of fish populations of five salt marshes along the Essex coastline, United Kingdom. Estuarine, Coastal and Shelf Science, 85(2), 247-256. http://dx.doi.org/10.1016/j.ecss.2009.08.008

Humbert, J.-F., \& Dorigo, U. (2005). Biodiversity and aquatic ecosystem functioning: A mini- review. Aquatic Ecosystem Health and Management, 8, 367-374. http://dx.doi.org/10.1080/14634980500457773

Hyslop, E. J. (1980). Stomach contents analysis-a review of methods and their application. Journal of Fish Biology, 17, 411-429. http://dx.doi.org/10.1111/j.10958649.1980.tb02775.x

Jin, B., Fu, C., Zhong J., Li, B., Chen, J. \& Wu, J., (2007). Fish utilization of a salt marsh intertidal creek in the Yangtze River estuary, China. Estuarine, Coastal and Shelf Science, 73, 844-852. http://dx.doi.org/10.1016/j.ecss.2007.03.025

Krebs, C. J. (1999). Ecological Methodology. Canada: Addison-Welsey Educational Publishers. p. 620.

Lévêque, C. (1995). Role and consequences of fish diversity in the functioning of African freshwater ecosystems: A review. Aquatic Living Resources, 8, 59-78.

Lima-Junior, S. E. \& Goitein, R. (2001). A new method for the analysis of fish stomach contents. Maringá, 23(2), 421-424.

Little, M. C., Reay, P. J. \& Grove, S. J. (1988). The fish community of an East African Mangrove Creek. Journal of Fish Biology, 32, 729 - 747. http://dx.doi.org/10.1111/j.10958649.1988.tb05413.x

Ofori-Danson, P. K. \& Kumi, G. N. (2006). Food and Feeding Habit of Sarotherodon melanotheron, Rüppell, 1852 (Pisces: Cichlidae) in Sakumo Lagoon, Ghana. West African Journal of Applied Ecology, 10, 9 - 18.

Paugy, D., Lévêque, C. \& Teugels, G. G. (2003). The Fresh and Brackish Water Fishes of West Africa. Vol. II. IRD Editions, Publications Scientifiques du Muséum, MRAC, 2003. p. 815 .

Pielou, E. C. (1966). The measurement of diversity in different types of biological collections. Journal of Theoretical Biology, 13, 131-144. http://dx.doi.org/10.1016/00225193(66)90013-0

Quashie, A. \& Oppong, D. (2006). Ghanaian Solar Saltworks: Promoting and Protecting 
the Ecology. Proceedings of the $1^{\text {st }}$ International Conference on the Ecological Importance of Solar Saltworks (CEISSA 06), Santorini Island, Greece, 20-22 ${ }^{\text {nd }}$ October 2006.

Quinn, N. J. (1980). Analysis of temporal changes in fish assemblages in Serpentine Creek, Queensland. Environmental Biology of Fishes, 5, 117-133. http://dx.doi.org/10.1007/BF02391619

Rutherford, C. T. (1971). Fresh-water Shrimps in the Area of Cape Coast, Ghana. Ghana Journal of Science, 11 (2), 87-91.

Ryan, J. M. \& Ntiamoa-Baidu, Y. (2000). Biodiversity and ecology of coastal wetlands in $\begin{array}{lllll}\text { Ghana. Biodiversity and } \quad \text { Conservation, } 9 & \text { (4), 445-446. }\end{array}$ http://dx.doi.org/10.1023/A:1008964000018

Scherer-Lorenzen, M. (2005). Biodiversity And Ecosystem Functioning: Basic Principles. In: W. Barthlott, K. E. Linsenmair, \& S. Porembski (Eds.) Biodiversity: Structure And Function. UK, Oxford: EOLSS Publishers. http://dx.doi.org/10.1007/b137862

Schneider, W. (1990). FAO species Identification for Fishery Purposes: Field Guide to the Commercial Marine Resources of the Gulf of Guinea. FAO pbl. RAFR/F1/90/2, Rome, 1990. p. 268.

Ugwumba, A. A. A. \& Adebisi, A. (1992). The Food and Feeding Ecology of Sarotherodon melanotheron (Ruppell) in a Small Freshwater Reservoir in Ibadan, Nigeria. Archiv fuer Hydrobiologie, 124(3), 367-382.

Ugwumba, A. A. A. (1988). Food and Feeding habits of juveniles of some culturable fish species in Nigeria. Nigerian Institute for Oceanography and Marine Research, Technical Paper No. 3. p 24.

Willoughby, N., Grimble, R., Ellenbroek, W., Danso, W. \& Amatekpor, J. (2001). The wise use of wetlands: identifying development options for Ghana's coastal Ramsar sites. Hydrobiologia, 458, 221-234. http://dx.doi.org/10.1023/A:1013158329107

Winemiller, K. O. \& Ponwith, B. J. (1998). Comparative ecology of eleotrid fishes in Central American coastal streams. Environmental Biology of Fishes, 53(4), 373 - 384. http://dx.doi.org/10.1023/A:1007422821071

Yankson, K. \& Obodai, E. A. (1999). An update of the number, types and distribution of coastal lagoons in Ghana. Journal of the Ghana Science Association (Special Edition), 2, $26-31$. 